\title{
THE REAL ESTATE MARKET IN THE RUSSIAN FEDERATION IN H1 2013
}

\author{
G.Zadonsky
}

In the first six months of 2013,278,200 apartments with the total floorspace of $22.6 \mathrm{~m}$ sq. meters were built. The average actual cost of building of $1 \mathrm{sq}$. meter rose by $11.8 \%$ in the first six months of 2013 as compared to the same period of 2012 and amounted to $R b 35,628$, while the ratio between the price of 1 sq. meter of housing on the primary market and the cost of building of 1 sq. meter decreased within the same period by 7.0 p.p. and amounted to $138.5 \%$. In the first six months of 2013, the volume of registration of individuals' titles to land plots increased by 5.9\% as compared to the first six months of 2012. In January-July 2013, 410,880 mortgage housing loans (MHL) worth $R b 663.6 b n$ were extended which figure exceeds by $28.1 \%$ the monetary volume of $M H L$ extended in January-July 2012. In July 2013, the average weighted monthly rate on MHL in rubles fell to $12.5 \%$.

According to the Rosstat's data, in the first six months of 2013, entities of all the forms of ownership built 278.200 apartments with total floorspace of $22.6 \mathrm{~m}$ sq. meters which is equal to $107.6 \%$ on the respective period of the previous year. Individual developers built $11.6 \mathrm{~m}$ sq. meters of housing or $51.5 \%$ of the total volume of housing commissioned in the first six months of 2013. In July 2013, entities of all the forms of ownership built 52,200 new apartments with the total floorspace of $4.2 \mathrm{~m}$ sq. meters which is $0.42 \%$ lower as regards the volume of floorspace than in July 2012, while in January-July they built 330,400 apartments with the total floorspace of $26.8 \mathrm{~m}$ sq. meters which is $6.2 \%$ higher as regards the volume of floorspace than in the respective period of 2012 (Fig. 1). According to the data of Rosstat, in August 201365,700 new apartments with the total floorspace of $5.1 \mathrm{~m} \mathrm{sq}$. meters were built, while from the beginning of the year $-396,100$ apartments with the total floorspace of $31.9 \mathrm{~m}$ sq. meters which figure is $8.1 \%$ higher as regards the volume of floorspace than in the respective period of 2012.

In the first six months of 2013, the largest volume of housing per 1,000 persons - over 300 sq meters - was commissioned in the Belgorod Region, the Moscow Region, the Krasnodar Territory, the Leningrad Region and the Republic of Tatarstan (Table 1). In the Belgorod Region - the leader of housing development $-80.9 \%$ of housing was commissioned by individual developers. As in the first six months of 2012, among federal districts the highest result (216.1 sq. meters per 1,000 persons) was registered with the Southern Federal District, while the lowest one -74.8 sq. meters per 1,000 persons of the population - with the Far Eastern Federal District (Table 1). As regards that index, Moscow was rated the $61^{\text {st }}$.

In the first six months of 2013, all the housing $100 \%$ - was commissioned by individual developers

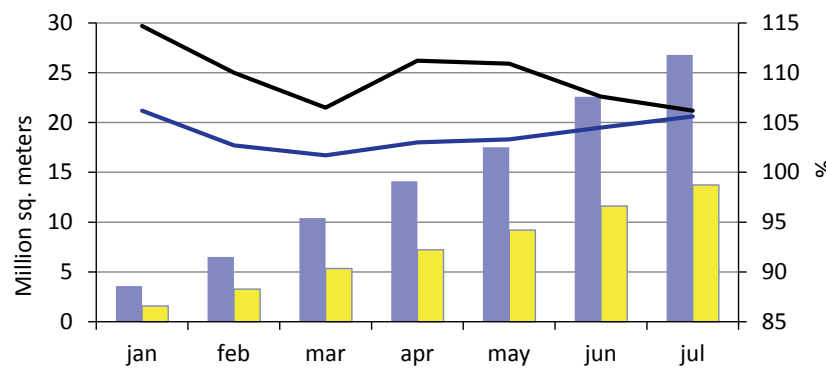

The total floorspace commissioned from the beginning of the year, million sq. meters

The floorspace commissioned by households of the total volume of floorspace as \% of the respective period of the previous year

-The total floorspace commissioned in the period from the beginning of the year, million sq. meters of floorspace

-The total floorspace commissioned in the period from the beginning of the year as $\%$ of the respective period of the previous year

Source: on the basis of the data of Rosstat.

Fig. 1. The dynamics of commissioning of housing in 2013

in the Jewish Autonomous Region, (the $45^{\text {th }}$ place) 125.1 sq. meters per 1,000 persons, in the Republic of Ingushetia (the $83^{\text {rd }}$ place) $-56.7 \mathrm{sq}$. meters and in the Chechen Republic (the $89^{\text {th }}$ place) -30.2 sq. meters.

According to the data of Rosstat, in the $2^{\text {nd }}$ quarter of 2013 the average actual cost of building of 1 sq. meter of floorspace of detached houses (apartment houses without additions, overstory and built-in premises and without dwelling houses built by individual developers) increased by $3.7 \%$ as compared to the $1^{\text {st }}$ quarter of 2013 and amounted to $\mathrm{Rb} 36,216$, while in the $1^{\text {st }}$ half-year of 2013 it rose by $11.8 \%$ as compared to the $1^{\text {st }}$ quarter of 2012 and amounted to $\mathrm{Rb} 35,628$ (Fig. 2). According to the data of Rosstat, in the first six months of 2013 the highest cost of development which exceeded by $50 \%$ or more the average national level was observed in the Nenetsk Autonomous Region ( $R b$ 52,333), the Sakhalin Region ( $R b$ 54,070), the Yamalo-Nenets Autonomous Region (Rb 54,627), the Magadan Region ( $R b$ 54,869), the Khabarov Ter- 
Table 1

DISTRIBUTION OF REGIONS OF THE RUSSIAN FEDERATION BY THE VOLUME OF HOUSING COMMISSIONED IN JANUARY-JUNE 2013 PER 1,000 PERSONS OF THE POPULATION

\begin{tabular}{|c|c|c|c|c|c|c|c|c|}
\hline \multirow[b]{2}{*}{ Region } & \multicolumn{4}{|c|}{$\begin{array}{l}\text { The place of the region } \\
\text { in the 1st half-year }\end{array}$} & \multicolumn{2}{|c|}{$\begin{array}{l}\text { Total floorspace com- } \\
\text { missioned in H1 } 2013\end{array}$} & \multicolumn{2}{|c|}{$\begin{array}{c}\text { Floorspace commissioned } \\
\text { by individual developers }\end{array}$} \\
\hline & 2013 & 2012 & 2011 & 2010 & $\begin{array}{l}\text { as } \% \text { of } \mathrm{H} 1 \\
2012\end{array}$ & $\begin{array}{c}\text { Sq. Me- } \\
\text { ters per } \\
1,000 \\
\text { persons }\end{array}$ & $\begin{array}{l}\% \text { of the total } \\
\text { floorspace } \\
\text { commissioned }\end{array}$ & $\begin{array}{l}\text { Place of } \\
\text { the region }\end{array}$ \\
\hline Belgorod Region & 1 & 3 & 5 & 8 & 119.1 & 357.76 & 80.9 & 15 \\
\hline Moscow Region* & 2 & 5 & 4 & 1 & 125.5 & 321.52 & 33.2 & 78 \\
\hline Krasnodar Territory & 3 & 1 & 1 & 2 & 92.4 & 318.38 & 55.8 & 46 \\
\hline Leningrad Region & 4 & 7 & 7 & 3 & 136.3 & 317.85 & 23.7 & 85 \\
\hline The Republic of Tatarstan & 5 & 4 & 2 & 5 & 109.5 & 313.92 & 61.4 & 40 \\
\hline Tyumen Region & 6 & 2 & 3 & 4 & 96.8 & 288.12 & 28.3 & 81 \\
\hline Lipetsk Region & 7 & 8 & 8 & 15 & 107.1 & 249.35 & 66.8 & 29 \\
\hline $\begin{array}{l}\text { The Republic of } \\
\text { Bashkortostan }\end{array}$ & 8 & 13 & 12 & 17 & 118.1 & 248.64 & 82.8 & 11 \\
\hline $\begin{array}{l}\text { The Republic of } \\
\text { Karachaevo-Cherkessia }\end{array}$ & 9 & 64 & 75 & 78 & 266.1 & 245.42 & 93.9 & 5 \\
\hline The Republic of Altai & 10 & 6 & 20 & 11 & 97.6 & 238.66 & 62.2 & 37 \\
\hline Kaliningrad Region & 11 & 10 & 6 & 6 & 100.7 & 227.49 & 34.7 & 74 \\
\hline Southern Federal District & 12 & 11 & 9 & 10 & 98 & 216.11 & 63.5 & 34 \\
\hline The Republic of Mariy-El & 13 & 14 & 11 & 16 & 103.5 & 214.82 & 64.8 & 33 \\
\hline Ulyanovsk Region & 14 & 15 & 25 & 39 & 101.3 & 205.65 & 66.7 & 31 \\
\hline Tambov region & 15 & 16 & 17 & 19 & 102.9 & 204.23 & 91.0 & 6 \\
\hline Kursk Region & 16 & 41 & 46 & 53 & 167.1 & 203.71 & 39.2 & 67 \\
\hline St. Petersburg & 19 & 53 & 14 & 12 & 175 & 188.44 & 4.0 & 91 \\
\hline Privolzhsky Federal District & 25 & 26 & 21 & 26 & 104.6 & 167.61 & 67.6 & 28 \\
\hline Central Federal District & 28 & 37 & 34 & 22 & 118.5 & 164.17 & 43.0 & 63 \\
\hline The Russian Federation & 29 & 33 & 30 & 25 & 107.6 & 157.60 & 51.5 & 51 \\
\hline Urals Federal District & 30 & 22 & 27 & 28 & 92.9 & 156.80 & 39.0 & 68 \\
\hline $\begin{array}{l}\text { North-Western } \\
\text { Federal District }\end{array}$ & 31 & 44 & 38 & 23 & 131.8 & 155.78 & 21.8 & 87 \\
\hline $\begin{array}{l}\text { North-Caucasian } \\
\text { Federal District }\end{array}$ & 41 & 35 & 49 & 33 & 92,3 & 130,02 & 62,9 & 35 \\
\hline Siberian Federal District & 48 & 48 & 41 & 44 & 107,6 & 123,17 & 54,6 & 48 \\
\hline Moscow* & 61 & 85 & 68 & 70 & 143,4 & 99,09 & 8,7 & 90 \\
\hline Far Eastern Federal District & 76 & 71 & 74 & 77 & 87,6 & 74,80 & 46,7 & 60 \\
\hline
\end{tabular}

* The data on the city of federal importance Moscow and the Moscow Region is provided with taking into account changes in their borders from July 1, 2012.

Source: on the basis of the data of Rosstat.

ritory ( $\mathrm{Rb} 57,396)$ and Chukot Autonomous Area (Rb 80,000). In 51 constituent entities of the Russian Federation, that cost was below the average national level with the lowest one registered in the Republic of Tyva ( $\mathrm{Rb} 11,331)$, Dagestan (Rb 17,457) and the Kursk Region ( $R b$ 21,851).

In the $2^{\text {nd }}$ quarter of 2013, the average price of 1 sq. meter of housing (Rb 49,331) increased by $1.1 \%$ against the $1^{\text {st }}$ quarter of 2013 (Fig. 2) having exceeded by $6.4 \%$ the average price of 1 sq. meter of housing in the $2^{\text {nd }}$ quarter of 2012. In the $2^{\text {nd }}$ quarter of 2013, the average price of $1 \mathrm{sq}$. meter of housing on the pri- mary housing market amounted to $88.1 \%$ of the average price of $1 \mathrm{sq}$. meter of housing on the secondary market; the above value is 1.2 p.p. higher than in the $2^{\text {nd }}$ quarter of 2012. In the $2^{\text {nd }}$ quarter of 2013 , the ratio between the price of 1 sq. meter of housing on the primary market and the cost of building of $1 \mathrm{sq}$. meter of housing amounted to $138.5 \%$ against $139.7 \%$ in the $1^{\text {st }}$ quarter of 2013 (Fig. 2).

According to the data of Rosreestr provided to the OAO Agency for Housing Mortgage Lending (OAO AHML) (Fig. 3), in the $2^{\text {nd }}$ quarter of 2013 the share of mortgaged real estate property in the total number of 
the real estate units registered in housing transactions increased by 2.9 p.p. on the $2^{\text {nd }}$ quarter of 2012 and amounted to $24.3 \%$.

According to the data of Rosreestr, in the first six months of 2013 the volume of registration of individuals' titles to land plots $(2,749,875$ certificates) increased by $5.9 \%$ as compared to the first six months of 2012. On the contrary, the number of legal entities' registered titles to land plots fell by $7.1 \%$ and amounted to 126,281 certificates in the first six months of 2012. In the first six months of 2013 , individuals' leasehold of land plots $(38,457$ certificates) decreased by $1.84 \%$ as compared to the first six months of 2012 , while leasehold by legal entities increased by $130 \%$.

As compared to the first six months of 2012, in the first six months of 2013 the number of registered mortgaged land plots rose by $19.7 \%(227,784$ certificates) and $11.9 \%$ (70,301 registered certificates) for individuals and legal entities, respectively.

According to the data of Rosreestr, the volume of registration in accordance with a simplified procedure (the summer cottage amnesty) of individuals' titles to land plots which were granted before the Land Code of the Russian Federation came into effect for personal husbandry, gardening, summer cottage building and individual garage or housing development keeps decreasing (Fig. 4) and amounted to 202,464 certificates in the first six months of 2013 which is $17.8 \%$ lower than in the first six months of 2012.

According to the data of the Central Bank of the Russian Federation, in January-July 2013 Rb 438.1bn worth of 438,099 housing loans were extended, including $\mathrm{Rb} 663.6 \mathrm{bn}$ worth of 410880 mortgage housing loans (MHL) which exceeds by $28.1 \%$ the monetary volume of MHL extended in January-July 2012. In July 2013, Rb 121.1bn worth of ruble MHL was extended which is $38.1 \%$ more than in July 2012 (Fig. 5) and $\mathrm{Rb} 8,496 \mathrm{~m}$ worth of MHL in foreign currency which is 17.2\% more than in July 2012.

In the period from April till July 2013, growth in the outstanding debt on MHL in rubles continued and as of August 1, 2013 the debt amounted to $\mathrm{Rb} 2,221.1 \mathrm{bn}$ which is $40.5 \%$ more than that as of August 1, 2012 (Fig. 5). As regards loans in foreign currency, as of August 1, 2012 the debt on MHL amounted to $\mathrm{Rb} 120.2 \mathrm{bn}$ which is $17.7 \%$ more than that as of August 1, 2012.

As of August 1, 2013, the overdue debt on MHL in rubles amounted to $\mathrm{Rb} 27.3 \mathrm{bn}$ (Fig. 5); it is to be noted that its share in the outstanding debt keeps falling and as of August 1, 2013 amounted to $1.2 \%$ which is 0.4 p.p. lower than that as of August 1, 2012. As of August 1,2012 , the overdue debt on MHL in foreign currency amounted to $\mathrm{Rb} 15.0 \mathrm{bn}$ or $12.5 \%$ of the out-

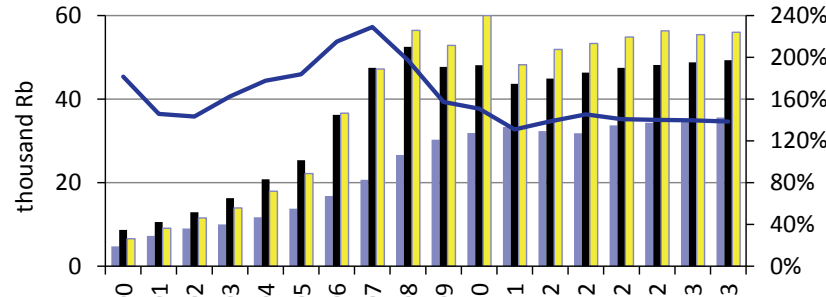

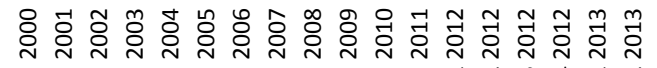

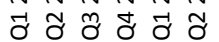

The average actual cost of building of $1 \mathrm{sq}$, meter of housing, $\mathrm{Rb}^{*}$

The average price of 1 sq. meter of housing on the primary market, $\mathrm{Rb}^{* *}$

$\square$ The average price of 1 sq. meter of housing on the secondary market. $\mathrm{Rb}^{* *}$

- The average price of 1 sq. meter of housing on the primary market as $\%$ of the average actual cost of building of 1 sq. meter of housing

* The average actual cost of building of 1 sq. meter of floorspace in detached dwelling houses (all the apartments) without additions, overstory and built-in premises in the Russian Federation (without those built by households at their own account and by means of borrowed funds);

** all the apartments.

Source: on the basis of the data of Rosstat.

Fig. 2. The dynamics of building of 1 sq. meter of housing and prices of $1 \mathrm{sq}$. meter of housing on the primary and secondary markets in the Russian Federation

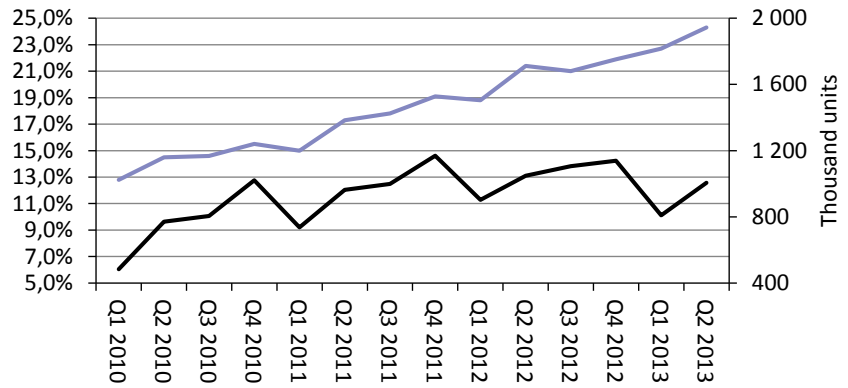

-The share of titles to mortgaged housing in the total number of titles to housing registered in housing transactions, \%

-The number of titles to housing registered in housing transactions, thousand units

Source: OAO AHML on the basis of the data of Rosreestr. Fig. 3. Dynamics of the number of real estate units registered in housing transactions and the shares of mortgaged real-estate units in the total number of real-estate units registered in housing transactions

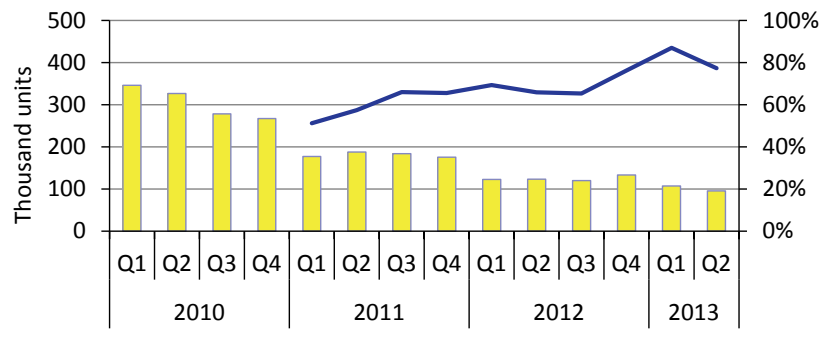

Registration within a quarter of individuals' titles to land plots in accordance with a simplified procedure. thousand units -Against the respective period of the previous year, $\%$

Source: on the basis of the data of Rosreestr.

Fig. 4. Dynamics of registration of individuals' titles to land plots in accordance with a simplified procedure 
standing debt which is 1.6 p.p. lower as compared to that as of August 1, 2012.

The average value of MHL in rubles in July 2013 increased by $6.9 \%$ as compared to July 2012 and amounted to $\mathrm{Rb} 1.6 \mathrm{~m}$ (Fig. 6). The average value of MHL in foreign currency in July 2013 (Rb 8.3m) exceeded more than five times over the respective value of $\mathrm{MHL}$ in rubles.

In 2013, the role of foreign currency in mortgage housing lending keeps going down. As of August 1, 2013 the share of MHL in foreign currency as regards the number of loans amounted to $0.3 \%$, while that as regards the volume and the outstanding debt, to $1.4 \%$ against $1.5 \%$ as of August 1, 2012 and 5.1\% against $8.3 \%$, respectively. Though the share of the overdue debt on loans in foreign currency as a percentage of the total overdue debt has been decreasing, the value of the share remains quite a significant one and exceeds 35\% as of August 1, 2013.

In 2012 and within the first six months of 2013, the volume of $\mathrm{MHL}$ extended from the beginning of the year in shares of GDP in current prices was growing steadily (Fig. 7). However, in the first six months of 2013 the volume of MHL in shares of GDP (1.7\%) was still 0.03 p.p. lower than the maximum value in the first six months of 2008. At the same time, the debt in shares of GDP on MHL extended in 2012 (3.2\%) exceeded by 0.6 p.p. the respective maximum value of the year 2009.

According to the data of the Central Bank of the Russian Federation, as of August 1, 2013 the debt on defaulted MHL (with a delay period of over 180 days) was $2.9 \%$ more than in the previous month ( $\mathrm{Rb} 26.9 \mathrm{bn}$ ), while as a percentage of the total sum of the debt amounted to $1.15 \%$ (Table 2) against $2.9 \%$ as of August 1,2012 . As of August 1, 2013, the share of the debt on MHL without overdue payments increased in money terms, but fell within a month by 0.24 p.p. as a percentage of the total sum of the debt (Table 2).

According to the data of the Central Bank of the Russian Federation, in July 2013 the average weighted rate on $\mathrm{MHL}$ in rubles extended within a month fell to $12.5 \%$ against the index of 2013 (Fig. 8). The respective rate on $\mathrm{HL}$ in rubles extended within a month decreased to the same value, as well. As of August 1 , 2013, the average weighted rates on MHL and $\mathrm{HL}$ in foreign currency extended from the beginning of the year fell each by 0.3 p.p. against the index of May 2013 and were both equal to $9.8 \%$.

The average weighted period of lending as regards $\mathrm{MHL}$ in rubles extended within a month preserved in July 2013 the same value of 14.7 years, while that as regards $\mathrm{HL}$ increased by 0.07 years and amounted to 14.5 years. As of August 1, 2013, the average weighted

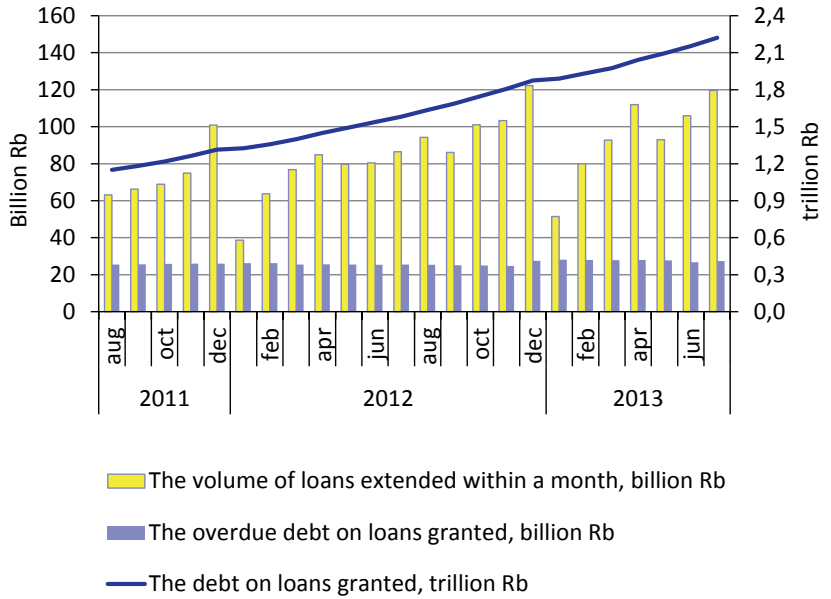

Source: on the basis of the data of the Central Bank of the Russian Federation.

Fig. 5. Dynamics of mortgage housing lending in rubles within a month

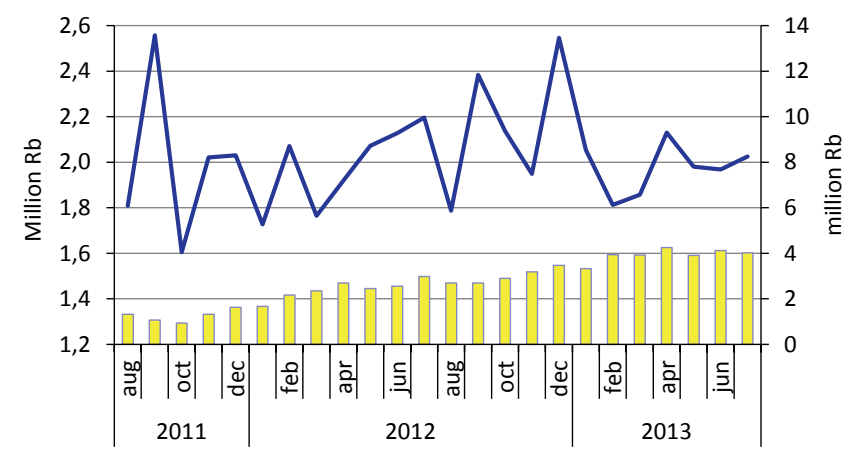

$\square$ The average value of a loan in rubles within a month, million $\mathrm{Rb}$ (left scale)

- The average value of a loan in foreign currency within a month, million $\mathrm{Rb}$ (right scale)

Source: on the basis of the data of the Central Bank of the Russian Federation.

Fig. 6. Dynamics of the monthly average value of $\mathrm{MHL}$

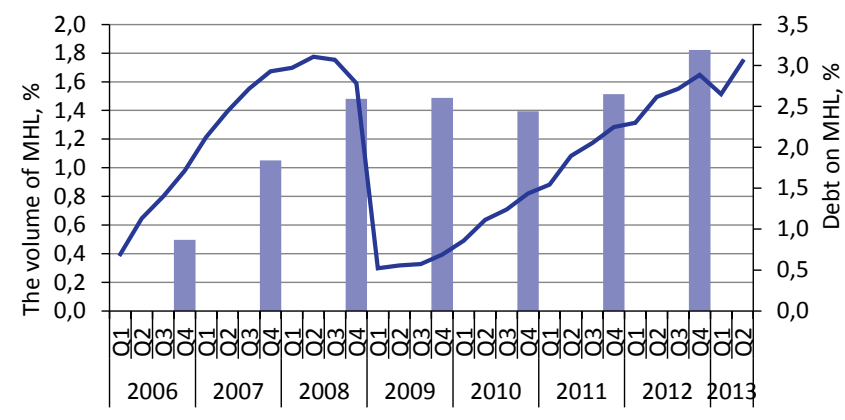

The debt on loans granted as \% of GDP within a year

- The volume of MHL granted with cumulative result within a year as $\%$ of the respective GDP in current prices

Source: on the basis of the data of Rosstat.

Fig. 7. The volume and debt on MHL granted as \% of GDP in current prices 
Table 2

GROUPING OF THE DEBT ON MORTGAGE HOUSING LOANS BY PERIODS OF DELAY IN PAYMENTS IN 2013

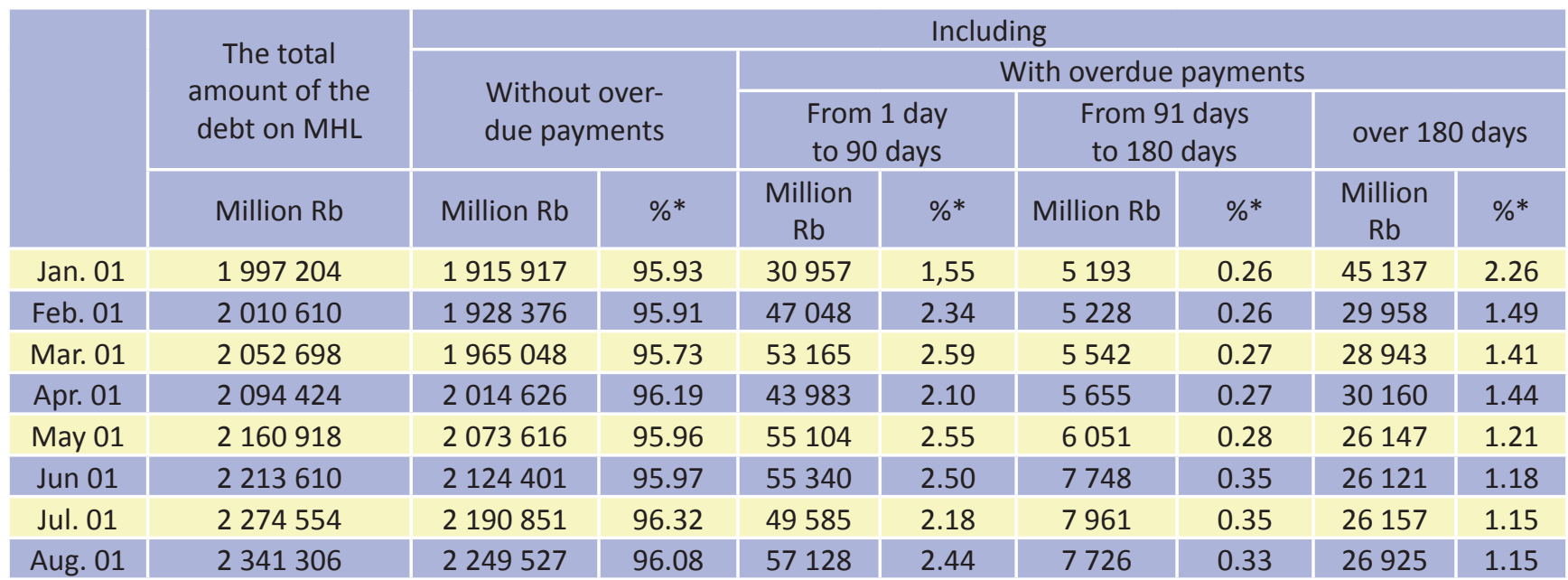

* as \% of the total sum of the debt.

Source: on the basis of the data of the Central Bank of the Russian Federation.

period of lending as regards MHL in foreign currency extended from the beginning of the year amounted to 12.9 years, while that as regards $\mathrm{HL}$ in foreign currency, to 11.0 years.

According to operation outputs of leading mortgage banks, in the first six months of 2013 the St. Petersburg Bank showed the highest threefold growth in the volume of the extended MHL as compared to the respective period of 2012 (Table 3), while Sberbank - the leader as regards the volume of lending - growth of $21.8 \%$. In the first six months of 2013 , Sberbank and VTB 24 account for over a half of the mortgage market as regards the volume of the extended MHL (61.7\%) which is $3.0 \mathrm{p}, \mathrm{p}$, more than in the respective period of 2012.

In the first six months of 2013, the total volume of the early repaid MHL as compared to the respective period of 2012 rose by $9.0 \%$, while early repay-

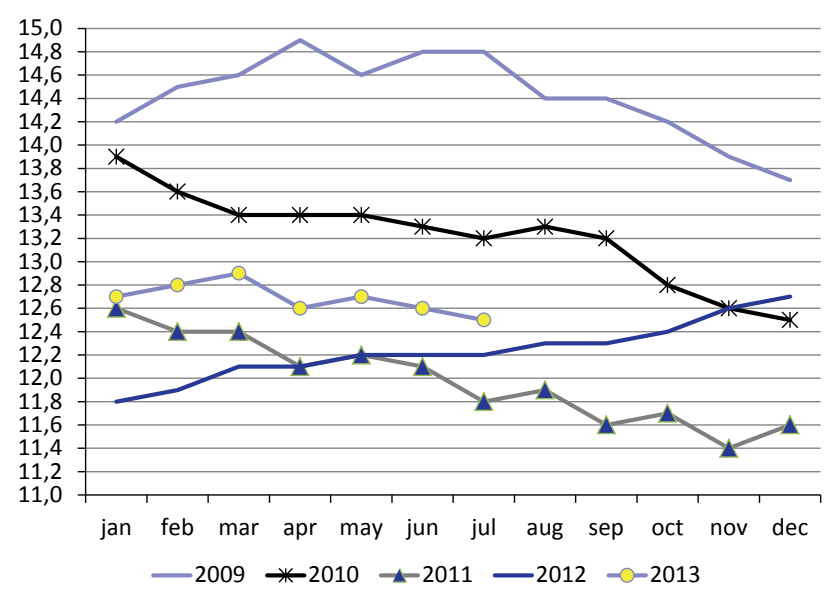

Source: on the basis of the data of the Central Bank of the Russian Federation.

Fig. 8. The average weighted interest rates on $\mathrm{MHL}$ in rubles extended within a month

THE OPERATION OUTPUTS OF THE LEADING MORTGAGE BANKS IN THE FIRST SIX MONTHS OF 2013

\begin{tabular}{|c|c|c|c|c|}
\hline No & Bank & $\begin{array}{l}\text { The volume of the } \\
\text { extended } \mathrm{MHL} \text {, million } \mathrm{Rb}\end{array}$ & $\begin{array}{c}\text { The number of the } \\
\text { extended } \mathrm{MHL}\end{array}$ & $\begin{array}{l}\text { Growth in the volume of the } \\
\text { extended loans as compared } \\
\text { to six months of } 2012, \%\end{array}$ \\
\hline 1 & Sberbank & 234203 & 167881 & 21.8 \\
\hline 2 & VTB 24 & 97669 & 60553 & 64 \\
\hline 3 & Gasprombank & 36032 & 16742 & 34.8 \\
\hline 4 & DeltaCredit & 11650 & 4208 & 14.6 \\
\hline 5 & Rosbank & 8434 & 3981 & 16 \\
\hline 6 & Svyaz-Bank & 8338 & 4242 & 49 \\
\hline 7 & Reiffeisenbank & 7540 & 2765 & 130.1 \\
\hline 8 & Khanty-Mansiisky Bank & 6160 & 2546 & 116.2 \\
\hline 9 & Absolut Bank & 6064 & 2871 & 79 \\
\hline 10 & St. Petersburg Bank & 5875 & 2862 & 200 \\
\hline
\end{tabular}

Source: the data of Rosipoteka. 
ment by means of the borrower's funds, by $4.1 \%$. Along with, the share of early repaid $\mathrm{MHL}$ as a percentage in the volume of the extended $\mathrm{MHL}$ fell by 4.2 p.p. as compared to the first six months of 2012 and amounted to $26.8 \%$ (Fig. 9). The share of borrowers' own funds in the volume of early repaid MHL amounted to $77.7 \%$.

According to the data of the Central Bank of the Russian Federation, in the first six months of 2013 on the primary MHL market 505 credit institutions out of 665 ones extended MHL, while 160 credit institutions serviced the earlier extended loans. In the first six months of 2013, 129 credit institutions refinanced $\mathrm{Rb} 49.2 \mathrm{bn}$ worth of $\mathrm{MHL}$ (Fig. 10). Within the same period in 2012, 149 credit institutions refinanced Rb 30.7bn worth of MHL. As of July 1, 2013, the share of refinanced $\mathrm{MHL}$ amounted to $9.1 \%$ of the volume of the extended MHL (Fig. 10) against $7.1 \%$ in the first six months of 2012. As of August 1, 2013, OAO AHML bought back Rb 26.2bn worth of 18,276 mortgages which amounted to $3.9 \%$ of the primary MHL market. In the first six months of 2013, OAO AHML bought back Rb 22.3bn worth of mortgages which is equal to $45.3 \%$ of the total volume of the refinanced $\mathrm{MHL}$.

According to the data of the Pension Fund of the Russian Federation, Russian families spent $94 \%$ out of $\mathrm{Rb} 645 \mathrm{bn}$ worth of the realized maternity capital on improvement of their housing conditions, including $66 \%$ of those funds on repayment of housing loans and credits and another $28 \%$ of funds on improvement of housing conditions without attracting loan funds.

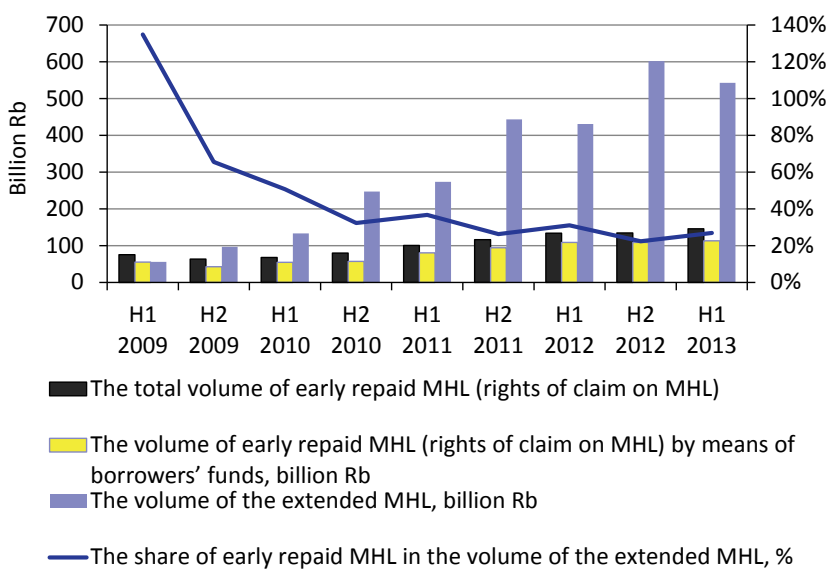

Source: on the basis of the data of the Central Bank of the Russian Federation.

Fig. 9. Dynamics of early repaid $\mathrm{MHL}$ (rights of claim)

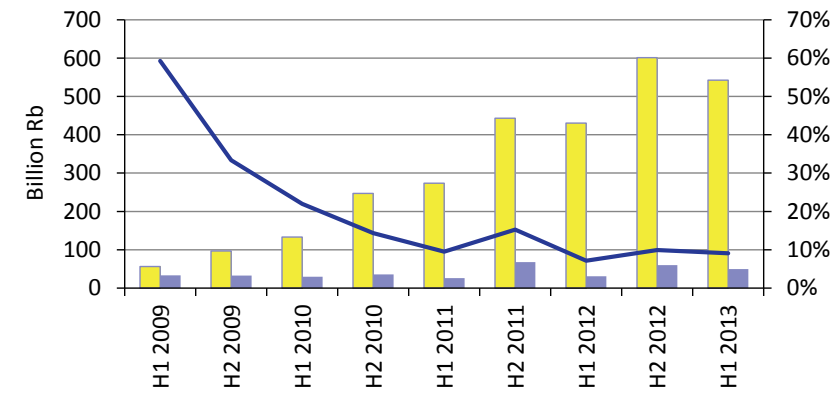

The volume of the extended MHL, billion $\mathrm{Rb}$

The volume of the refinanced $\mathrm{MHL}$ (rights of claim), billion $\mathrm{Rb}$

- The share of the refinanced MHL in the volume of the extended MHL, \%

Source: on the basis of the data of the Central Bank of the Russian Federation.

Fig. 10. Dynamics of refinancing of $M H L$ (rights of claim) through sale to other entities 